\title{
PENGARUH PEMBERIAN PUPUK GAMBUT DAN UREA TERHADAP PERTUMBUHAN BIBIT KELAPA SAWIT (Elaeis guineensis Jacq.) PADA PEMBIBITAN PRE NURSERY
}

\author{
MOHAMMAD HERTOS \\ Dosen Program Studi Agroteknologi Fakultas Pertanian dan Kehutanan \\ Universitas Muhammadiyah Palangkaraya
}

\begin{abstract}
The purpose of this research was to find Pugam T and Urea interactions on the growth for Oil Palm in Pre Nursery to Peat Soil. The research were arranged in Completely Randomised with two factors and three duplications. This first factor was to find Pugam $T(P)$ on four levels: $0 \mathrm{~kg} / \mathrm{ha}\left(P_{0}\right), 750 \mathrm{~kg} / \mathrm{ha}\left(P_{1}\right)$, $1000 \mathrm{~kg} / \mathrm{ha}\left(P_{2}\right)$ and $1.250 \mathrm{~kg} / \mathrm{ha}\left(P_{3}\right)$, the second factor was Urea $(N)$ on four levels: $0 \mathrm{~g} / \mathrm{l}\left(N_{0}\right), 1 \mathrm{~g} / \mathrm{l}\left(N_{1}\right)$, $2 \mathrm{~g} / \mathrm{l}\left(\mathrm{N}_{2}\right)$ and $3 \mathrm{~g} / \mathrm{l}\left(\mathrm{N}_{3}\right)$.

The results show the experiment of treatmants Pugam $T$ and Urea was significantly on the parameters: plant heigth, stem of diameters, weigth fresh of plant and root lengths of primers. The heighest yield to parameters of plant heigth in old 4,8 and $12 \mathrm{MST}(10,57 \mathrm{~cm}, 31,03 \mathrm{~cm}$ and 35,00 cm), stem of diameters in old 4,8 and $12 \mathrm{MST}(0,57 \mathrm{~cm}, 0,66 \mathrm{~cm}$ and 0,90 cm), weigth fresh of plant $(16,8 \mathrm{~g})$ and root lengths of primers $(26,08 \mathrm{~cm})$. Obtainable on the treatmants to find Pugam T as big as $1.250 \mathrm{~kg} / \mathrm{ha}$ and Urea as big as $3 \mathrm{~g} / \mathrm{l}\left(\mathrm{P}_{3} \mathrm{~N}_{3}\right)$.
\end{abstract}

Keywords: pugam, urea, oil palm, pre nursery

\section{ABSTRAK}

Penelitian ini bertujuan untuk mengetahui interaksi pengaruh pemberian dosis pupuk Pugam $T$ dan Urea terhadap pertumbuhan bibit kelapa sawit pada pembibitan pre nursery. Percobaan ini menggunakan Rancangan Acak Lengkap (RAL) Faktorial dengan dua faktor dan tiga ulangan. Faktor I : Perlakuan pemberian Pugam T $(P)$ yang terdiri dari 4 taraf, yaitu : $P_{0}=0 \mathrm{~kg} / \mathrm{ha}, P_{1}=750 \mathrm{~kg} / \mathrm{ha}, P_{3}=1.000 \mathrm{~kg} / \mathrm{ha}$ dan $\mathrm{P}_{3}=1.250 \mathrm{~kg} / \mathrm{ha}$. Faktor II : Perlakuan pemberian Urea (N) yang terdiri dari 4 taraf, yaitu : $\mathrm{N}_{0}=0$ gram/liter, $\mathrm{N}_{1}=1 \mathrm{gram} /$ liter, $\mathrm{N}_{2}=2 \mathrm{gram} / \mathrm{iter}$ dan $\mathrm{N}_{3}=3 \mathrm{gram} / \mathrm{liter}$.

Hasil penelitian yang diperoleh menunjukkan bahwa perlakuan pemberian Pugam $\mathrm{T}$ dan Urea berpengaruh sangat nyata terhadap parameter tinggi tanaman, diameter batang, berat segar tanaman dan panjang akar primer.

Hasil tertinggi untuk parameter tinggi tanaman umur 4, 8 dan $12 \mathrm{MST}(10,57 \mathrm{~cm}, 31,03 \mathrm{~cm}$, dan 35,00 $\mathrm{cm})$, diameter batang umur 4,8 dan $12 \mathrm{MST}(0,57 \mathrm{~cm}, 0,66 \mathrm{~cm}$ dan $0,90 \mathrm{~cm})$, berat segar tanaman $(16,68$ gram) dan panjang primer $(26,08 \mathrm{~cm})$ diperoleh pada perlakuan pemberian Pugam T sebesar $1.250 \mathrm{~kg} / \mathrm{ha}$ dan Urea sebesar 3 gram/liter $\left(\mathrm{P}_{3} \mathrm{~N}_{3}\right)$.

Kata kunci: pugam, urea, kelapa sawit, pembibitan pre nursery

\section{PENDAHULUAN}

Kelapa sawit (Elaeis guineensis Jacg) merupakan salah satu tanaman penghasil minyak nabati yang sangat penting. Dimasa kini kelapa sawit tumbuh sebagai tanaman budidaya yang tersebar di berbagai negara beriklim tropis bahkan subtropis di Asia, Amerika Selatan dan Afrika (Setyamidjaja, 2006).
Bagi Indonesia tanaman kelapa sawit memiliki arti penting bagi pembangunan perkebunan nasional; selain mampu menciptakan kesempatan kerja yang mengarah pada kesejahteraan masyarakat, juga sebagai sumber perolahan devisa negara; masa depan agrobisnis kelapa sawit menunjukkan peran yang sangat signifikan bagi ekonomi Indonesia; perkembangan 
luas dan produksi perkebunan kelapa sawit di Indonesia selama sepuluh tahun terakhir telah meningkat dari 1.592.000 hektar pada tahun 1997 menjadi 6.513 .000 hektar pada tahun 2007 atau meningkat $75 \%$ pertahun; produksi juga meningkat dari 5.448 .000 ton pada tahun 1997 menjadi 17.300 .000 ton pada tahun 2007; hal ini menjadikan Indonesia mampu melampaui produksi minyak sawit malaysia (Sunarko, 2009).

Perkebunan kelapa sawit di Indonesia luasnya telah mencapai lebih dari lima juta hektar, sehingga merupakan komoditi perkebunan terluas di Indonesia maupun dunia; namun sangat di sayangkan produktivitasnya masih rendah dan penyebarannya di tanah air tidak merata; lahan perkebunan paling luas berada di pulau sumatera dan kalimantan( Anonim, 2008b; Anonim, 2009a).

Salah satu aspek terpenting agar tercapainya produksi panen yang maksimal adalah tersedianya bahan tanam (bibit) yang berkualitas; bibit kelapa sawit yang berkualitas umumnya dihasilkan dari varietas yang unggul dan proses pembibitan yang baik (Anonim, 2008b). Pembibitan kelapa sawit merupakan titik awal yang paling menentukan masa depan pertumbuhan kelapa sawit di lapangan; bibit yang unggul merupakan modal dasar untuk mencapai produktivitas yang tinggi. Standar bibit yang baik dapat dilihat dari dari diameter batang (tegak), tinggi bibit (jagur), jumlah daun (cukup) dan tidak terlihat terserang hama dan penyakit; seleksi bibit harus dilakukan dengan ketat secara bertahap mulai dari penerimaan kecambah sampai seleksi yang terakhir pada saat pemindahan kelapangan (transplanting); seleksi bibit ketat karena bibit yang standar akan menentukan masa depan hasil panen dan kualitas tanaman (Anonim, 2009).
Proses pembibitan yang baik dapat dilakukan antara lain dengan menyediakan sejumlah unsur hara untuk memenuhi pertumbuhan bibit selama di pembibitan. Salah satu cara yang dapat dilakukan untuk memperbaiki kesuburan tanah adalah dengan melakukan pemupukan, baik dengan pupuk organik maupun anorganik (Anonim, 2008). Salah satu upaya yang dapat dilakukan untuk terciptanya kondisi yang baik pada media pembibitan kelapa sawit di pembibitan pre nursery adalah pemberian pupuk gambut dan urea.

Tanah gambut juga diketahui kahat unsur mikro karena dikhelat (diikat) oleh bahan organik (Rachim, 1995). Oleh karenanya diperlukan pemupukan unsur mikro seperti terusi, dan seng sulfat masing-masing $15 \mathrm{~kg} / \mathrm{ha} /$ tahun, mangan sulfat $7 \mathrm{~kg} / \mathrm{ha}$, sodium molibdat dan borax masing-masing $0,5 \mathrm{~kg} / \mathrm{ha} / \mathrm{th}$. Amelioran alami yang mengandung kation polivalen ( $\mathrm{Fe}, \mathrm{Al}, \mathrm{Cu}$ dan $\mathrm{Zn}$ ) seperti terak baja, tanah mineral laterit atau lumpur sungai sangat efektif mengurangi dampak buruk asam fenolat (Salampak, 1999; Supiandi et al, 1995). Pemberian tanah mineral berkadar besi tinggi dapat meningkatkan pertumbuhan dan produksi tanaman padi (Mario, 2002; Salampak, 1999; Suastika, 2004; Subiksa et al., 1997). Formula amelioran dan pupuk Pugam yang dikembangkan Balittanah juga efektif meningkatkan produktivitas lahan. Pugam juga mengandung kation polivalen dengan konsentrasi tinggi sehingga dosis yang diperlukan tidak terlalu besar, hanya $750 \mathrm{~kg} / \mathrm{ha}$ (Subiksa et al., 2009).

Sebagai unsur hara pembangun atau yang utama, pupuk urea, mengandung nitrogen (N) mempunyai peran yang sangat penting dalam setiap proses fisiologis tanaman. Unsur 
ini merupakan pembentuk utama sel protoplasma, protein, asam amino, amida dan alkaloid. Zat hijau daun juga banyak mengandung unsur hara $\mathrm{N}$, sehingga bila kekurangan unsur ini akan mengakibatkan penurunaan aktifitas metabolisme yang ditandai dengan gejala warna memucat.

Penelitian ini bertujuan untuk mengetahui interaksi pengaruh dosis pupuk gambut dan urea terhadap pertumbuhan bibit kelapa sawit pada pembibitan pre nursery dan untuk mengetahui pengaruh faktor tunggal pemberian dosis pupuk gambut dan urea terhadap pertumbuhan bibit kelapa sawit pada pembibitan pre nursery.

\section{METODOLOGI}

Penelitian ini dilaksanakan selama bulan Januari sampai Maret 2014, bertempat di rumah kaca BPTP Kalimantan Tengah Jl. G.Obos Km. 5 Palangka Raya.

Bahan-bahan yang digunakan pada penelitian ini adalah : bibit kelapa sawit dengan varietas Yangambi berasal dari PT. GSIP Indonesia, Pupuk Gambut T (PUGAM T), Urea, tanah gambut dan polybag ukuran $1 \mathrm{~kg}$. Alatalat yang digunakan dalam penelitian ini adalah : meteran, timbangan, pisau, kamera, cangkul, ember, gayung dan alat tulis.

Penelitian ini merupakan percobaan faktorial dengan dua faktor yang disusun berdasarkan Rancangan Acak Lengkap (RAL) dengan tiga ulangan. Faktor $\mathrm{I}$ : pemberian pugam $T(P)$ yang terdiri dari 4 taraf, yaitu : $P_{0}=0 \mathrm{~kg} / \mathrm{ha}$ (kontrol); $\mathrm{P}_{1}=750 \mathrm{~kg} / \mathrm{ha}(1,875$ gram/polybag $) ; \quad P_{2}=1.000 \mathrm{~kg} / \mathrm{ha} \quad(2,500$ gram/polybag); dan $P_{3}=1.250 \mathrm{~kg} / \mathrm{ha}(3,125$ gram/polybag).
Faktor II : pemberian urea $(\mathrm{N})$ yang terdiri dari 4 taraf, yaitu : $\mathrm{N}_{0}=0 \mathrm{gram} /$ liter (kontrol); $\mathrm{N}_{1}=1$ gram/liter $(1 \mathrm{mg} / 10 \mathrm{ml} /$ polybag $)$; $\mathrm{N}_{2}=2$ gram/liter $(2 \mathrm{mg} / 10 \mathrm{ml} /$ polybag $)$; dan $\mathrm{N}_{3}=3 \mathrm{gram} /$ liter ( $3 \mathrm{mg} / 10 \mathrm{ml} /$ polybag).

Tanah yang digunakan untuk media tanam adalah tanah gambut yang diambil dari Kelurahan Kalampangan, Kecamatan Sabangau, Kota Palangka Raya. Tanah gambut diambil pada kedalaman $0-20 \mathrm{~cm}$. Kemudian di kering anginkan selama satu minggu pada tempat terbuka. Setelah kering tanah di hancurkan dan diayak dengan menggunakan ayakan tanah berukuran 100 mesh. Tanah ditimbang sebanyak $1 \mathrm{~kg}$, kemudian dicampur dengan Pugam $T$ sesuai dengan dosis perlakuan, kemudian dimasukkan ke dalam polybag dan diinkubasi selama 2 minggu sebelum tanam.

Bibit kelapa sawit yang masih berbentuk kecambah ditanam pada polybag dengan cara membuat lubang pada media tanam sesuai dengan panjang akar yang telah berkembang. Setelah ditanam dilakukan penutupan dengan tanah kembali secukupnya. Pemberian dosis pupuk urea dengan dilakukan pada minggu ke 2 dan ke 6 setelah tanam dengan cara dicampurkan dengan air dengan dosis sesuai dengan masing-masing perlakuan.

Pemeliharaan tanaman selama percobaan dilakukan secara intensif yang meliputi: penyulaman, penyiraman, penyiangan dan pengendalian hama dan penyakit. Penyulaman dilakukan pada bibit kelapa sawit yang tumbuhnya tidak normal atau mati maksimal pada umur 2 mst. 
Penyiraman dilakukan 2 kali sehari, yaitu pagi dan sore hari dengan volume penyiraman yang sama pada masing-masing polybag. Penyiraman dilakukan dari saat tanam hingga akhir penelitian.

Pengendalian gulma dilakukan dengan cara manual, yaitu dengan cara mencabut gulma yang tumbuh disekitar tanaman. Pengendalian hama dan penyakit dilakukan dengan cara fisik yaitu mematikan hama yang ada pada tanaman.

Parameter yang diamati pada penelitian ini adalah :

1. Tinggi bibit $(\mathrm{cm})$

Tinggi tanaman diukur dari pangkal batang hingga tajuk tanaman tertinggi, pengamatan dilakukan pada saat tanaman pada berumur 4,8 dan 12 MST.

2. Jumlah daun (helai)

Pengamatan jumlah daun dilakukan dengan cara menghitung jumlah helaian daun pada minggu 4.8 dan $12 \mathrm{MST}$.

3. Diameter batang $(\mathrm{cm})$

Diameter batang diukur menggunakan jangka sorong pada tanaman $(5 \mathrm{~cm}$ diatas pangkal batang), di ukur pada berumur 4,8,12 MST.

4. Berat segar bibit (gram)

Pengamatan berat segar bibit dilakukan setelah pembongkaran bibit, dengan cara menimbang bagian tajuk dan akar tanaman (dilakukan akhir pengamatan).

5. Panjang akar primer

Pengukuran panjang akar primer dilakukan dengan mencabut tanaman dan membersihkan dari tanah yang lengket pada akar dengan air, kemudian diukur satu persatu (dilakukan akhir pengamatan).
Data dianalisis dengan menggunakan analisis ragam (uji f) pada taraf $5 \%$ dan $1 \%$, apabila uji $\mathrm{F}$ menunjukkan adanya pengaruh perlakuan, maka dilanjutkan dengan uji beda rata-rata menggunakan $\mathrm{BNJ}$ pada taraf $5 \%$.

\section{HASIL DAN PEMBAHASAN}

Hasil Penelitian

Tinggi Bibit

Hasil analisis ragam menunjukkan bahwa interaksi perlakuan pemberian Pugam T dan Urea berpengaruh sangat nyata terhadap tinggi bibit kelapa sawit umur 4, 8, dan 12 MST. Hasil uji beda rata-rata untuk parameter tinggi bibit kelapa sawit disajikan pada Tabel 1.

Pada Tabel 1 terlihat bahwa rata-rata tinggi bibit kelapa sawit tertinggi pada umur 4, 8, dan 12 MST dihasilkan oleh perlakuan interaksi pemberian Pugam $T$ dengan dosis $1.250 \mathrm{~kg} / \mathrm{ha}$ dan Urea dengan dosis 3 gram/liter $\left(\mathrm{P}_{3} \mathrm{~N}_{3}\right)$ dengan rata-rata setinggi $10,57 \mathrm{~cm}, 31,03 \mathrm{~cm}$ dan 35,00 $\mathrm{cm}$ dan berbeda nyata terhadap semua perlakuan lainnya.

\section{Jumlah Daun}

Hasil analisis ragam menunjukkan bahwa perlakuan pemberian Pugam $T$ dan Urea secara tunggal, maupun interaksi kedua perlakuan tersebut tidak berpengaruh nyata terhadap parameter jumlah daun umur 4,8 dan 12 MST.

\section{Diameter Batang}

Hasil analisis ragam menunjukkan bahwa interaksi perlakuan pemberian Pugam T dan Urea berpengaruh sangat nyata terhadap parameter diameter batang umur 4, 8, dan 12 MST. Hasil uji beda rata-rata untuk parameter diameter batang disajikan pada Tabel 2. 
Tabel 1. Hasil uji beda rata-rata tinggi bibit kelapa sawit umur 4, 8, dan 12 MST

\begin{tabular}{cccc}
\hline \multirow{2}{*}{ Perlakuan } & \multicolumn{3}{c}{ Tinggi Bibit } \\
\cline { 2 - 4 } & $\mathbf{4} \mathbf{M S T}$ & $\mathbf{8} \mathbf{M S T}$ & $\mathbf{1 2} \mathbf{M S T}$ \\
\hline $\mathrm{P}_{0} \mathrm{~N}_{0}$ & $4,76 \mathrm{a}$ & $21,60 \mathrm{a}$ & $23,50 \mathrm{a}$ \\
$\mathrm{P}_{0} \mathrm{~N}_{1}$ & $4,87 \mathrm{ab}$ & $22,37 \mathrm{ab}$ & $23,73 \mathrm{ab}$ \\
$\mathrm{P}_{0} \mathrm{~N}_{2}$ & $4,93 \mathrm{ab}$ & $22,47 \mathrm{ab}$ & $23,83 \mathrm{abc}$ \\
$\mathrm{P}_{0} \mathrm{~N}_{3}$ & $5,00 \mathrm{ab}$ & $22,57 \mathrm{abc}$ & $24,17 \mathrm{abcd}$ \\
$\mathrm{P}_{1} \mathrm{~N}_{0}$ & $5,37 \mathrm{~b}$ & $23,50 \mathrm{dcd}$ & $24,27 \mathrm{abcd}$ \\
$\mathrm{P}_{1} \mathrm{~N}_{1}$ & $6,17 \mathrm{C}$ & $23,73 \mathrm{~cd}$ & $24,63 \mathrm{abcd}$ \\
$\mathrm{P}_{1} \mathrm{~N}_{2}$ & $7,17 \mathrm{~b}$ & $23,83 \mathrm{de}$ & $24,83 \mathrm{bcde}$ \\
$\mathrm{P}_{1} \mathrm{~N}_{3}$ & $7,20 \mathrm{~d}$ & $24,17 \mathrm{dif}$ & $25,00 \mathrm{cde}$ \\
$\mathrm{P}_{2} \mathrm{~N}_{0}$ & $7,50 \mathrm{de}$ & $24,40 \mathrm{difg}$ & $25,50 \mathrm{dif}$ \\
$\mathrm{P}_{2} \mathrm{~N}_{1}$ & $8,03 \mathrm{ef}$ & $24,40 \mathrm{difg}$ & $26,00 \mathrm{efg}$ \\
$\mathrm{P}_{2} \mathrm{~N}_{2}$ & $8,20 \mathrm{f}$ & $24,63 \mathrm{difg}$ & $26,33 \mathrm{fg}$ \\
$\mathrm{P}_{2} \mathrm{~N}_{3}$ & $8,50 \mathrm{fg}$ & $25,00 \mathrm{ifg}$ & $26,83 \mathrm{~g}$ \\
$\mathrm{P}_{3} \mathrm{~N}_{0}$ & $9,03 \mathrm{gh}$ & $25,33 \mathrm{fg}$ & $28,33 \mathrm{~h}$ \\
$\mathrm{P}_{3} \mathrm{~N}_{1}$ & $9,23 \mathrm{~h}$ & $25,57 \mathrm{~g}$ & $29,10 \mathrm{~h}$ \\
$\mathrm{P}_{3} \mathrm{~N}_{2}$ & $9,53 \mathrm{~h}$ & $25,60 \mathrm{~g}$ & $31,37 \mathrm{i}$ \\
$\mathrm{P}_{3} \mathrm{~N}_{3}$ & $10,57 \mathrm{i}$ & $31,03 \mathrm{~h}$ & $35,00 \mathrm{j}$ \\
\hline $\mathrm{BNJ}_{5}$ & 0,53 & 1,25 & 1,18 \\
\hline
\end{tabular}

Keterangan : Angka-angka yang didampingi huruf yang sama pada kolom yang sama tidak berbeda nyata pada uji BNJ taraf $5 \%$.

Tabel 2. Hasil uji beda rata-rata diameter batang umur 4, 8 dan 12 MST

\begin{tabular}{cccc}
\hline \multirow{2}{*}{ Perlakuan } & \multicolumn{3}{c}{ Diameter Batang } \\
\cline { 2 - 4 } & $\mathbf{4} \mathbf{M S T}$ & $\mathbf{8} \mathbf{M S T}$ & $\mathbf{1 2} \mathbf{M S T}$ \\
\hline $\mathrm{P}_{0} \mathrm{~N}_{0}$ & $0,16 \mathrm{a}$ & $0,21 \mathrm{a}$ & $0,26 \mathrm{a}$ \\
$\mathrm{P}_{0} \mathrm{~N}_{1}$ & $0,20 \mathrm{ab}$ & $0,21 \mathrm{a}$ & $0,30 \mathrm{ab}$ \\
$\mathrm{P}_{0} \mathrm{~N}_{2}$ & $0,20 \mathrm{ab}$ & $0,22 \mathrm{a}$ & $0,32 \mathrm{bc}$ \\
$\mathrm{P}_{0} \mathrm{~N}_{3}$ & $0,20 \mathrm{ab}$ & $0,23 \mathrm{a}$ & $0,33 \mathrm{bc}$ \\
$\mathrm{P}_{1} \mathrm{~N}_{0}$ & $0,21 \mathrm{abc}$ & $0,26 \mathrm{ab}$ & $0,37 \mathrm{~cd}$ \\
$\mathrm{P}_{1} \mathrm{~N}_{1}$ & $0,22 \mathrm{bc}$ & $0,30 \mathrm{bc}$ & $0,42 \mathrm{de}$ \\
$\mathrm{P}_{1} \mathrm{~N}_{2}$ & $0,22 \mathrm{bc}$ & $0,32 \mathrm{~cd}$ & $0,43 \mathrm{ef}$ \\
$\mathrm{P}_{1} \mathrm{~N}_{3}$ & $0,22 \mathrm{bc}$ & $0,33 \mathrm{~cd}$ & $0,45 \mathrm{ef}$ \\
$\mathrm{P}_{2} \mathrm{~N}_{0}$ & $0,23 \mathrm{bc}$ & $0,36 \mathrm{de}$ & $0,47 \mathrm{ef}$ \\
$\mathrm{P}_{2} \mathrm{~N}_{1}$ & $0,26 \mathrm{~cd}$ & $0,41 \mathrm{ef}$ & $0,48 \mathrm{f}$ \\
$\mathrm{P}_{2} \mathrm{~N}_{2}$ & $0,31 \mathrm{de}$ & $0,42 \mathrm{fg}$ & $0,54 \mathrm{~g}$ \\
$\mathrm{P}_{2} \mathrm{~N}_{3}$ & $0,33 \mathrm{e}$ & $0,44 \mathrm{fg}$ & $0,56 \mathrm{~g}$ \\
$\mathrm{P}_{3} \mathrm{~N}_{0}$ & $0,36 \mathrm{e}$ & $0,47 \mathrm{~g}$ & $0,66 \mathrm{~h}$ \\
$\mathrm{P}_{3} \mathrm{~N}_{1}$ & $0,44 \mathrm{f}$ & $0,54 \mathrm{~h}$ & $0,74 \mathrm{e}$ \\
$\mathrm{P}_{3} \mathrm{~N}_{2}$ & $0,50 \mathrm{~g}$ & $0,57 \mathrm{~h}$ & $0,82 \mathrm{j}$ \\
$\mathrm{P}_{3} \mathrm{~N}_{3}$ & $0,57 \mathrm{~h}$ & $0,66 \mathrm{i}$ & $0,90 \mathrm{k}$ \\
\hline $\mathrm{BNJ}_{5} \%$ & 0,05 & 0,05 & 0,05 \\
\hline
\end{tabular}

Keterangan : Angka-angka yang didampingi huruf yang sama pada kolom yang sama tidak berbeda nyata pada uji BNJ taraf $5 \%$.

Pada Tabel 2 terlihat bahwa rata-rata diameter batang terbesar umur 4, 8, dan 12 MST dihasilkan oleh perlakuan interaksi pemberian Pugam $\mathrm{T}$ dengan dosis $1.250 \mathrm{~kg} / \mathrm{ha}$ dan Urea dengan dosis 3 gram/liter $\left(\mathrm{P}_{3} \mathrm{~N}_{3}\right)$ dengan rata-rata diameter batang sebesar $0,57 \mathrm{~cm}, 0,66 \mathrm{~cm}$ dan $0,90 \mathrm{~cm}$ dan berbeda nyata terhadap semua perlakuan lainnya. 


\section{Berat Segar Bibit dan Panjang Akar Primer}

Hasil analisis ragam menunjukkan bahwa interaksi perlakuan pemberian Pugam $\mathrm{T}$ dan Urea berpengaruh sangat nyata terhadap parameter berat segar bibit dan panjang akar primer. Hasil uji beda rata-rata kedua parameter tersebut disajikan pada Tabel 3.

Pada Tabel 3 terlihat bahwa rata-rata berat segar bibit dan panjang akar primer terbesar dihasilkan oleh perlakuan interaksi pemberian Pugam T dengan dosis $1.250 \mathrm{~kg} / \mathrm{ha}$ dan Urea dengan dosis 3 gram/liter $\left(\mathrm{P}_{3} \mathrm{~N}_{3}\right)$ rata-rata sebesar 16,68 gram (berat segar bibit) dan 26,08 cm (panjang akar primer) dan berbeda nyata terhadap semua perlakuan lainnya.

\section{Pembahasan}

Perlakuan pemberian Pugam $\mathrm{T}$ dan Urea secara bersama-sama berpengaruh sangat nyata terhadap parameter tinggi bibit, diameter batang, berat segar bibit dan panjang akar primer.
Untuk parameter jumlah daun, perlakuan pemberian Pugam $\mathrm{T}$ dan Urea secara tunggal maupun kombinasi kedua perlakuan tersebut tidak berpengaruh nyata atau sangat nyata pada setiap umur pengamatannya.

Pada parameter tinggi bibit, hasil tertinggi diperoleh pada perlakuan pemberian Pugam $T$ sebesar $1.250 \mathrm{~kg} / \mathrm{ha}$ dan Urea sebesar 3 gram/liter $\left(\mathrm{P}_{3} \mathrm{~N}_{3}\right)$. Hal ini disebabkan karena kombinasi perlakuan tersebut mampu menyediakan unsur hara yang lebih optimal dibanding kombinasi perlakuan lainnya sehingga pertumbuhan tanaman dapat lebih dipacu, termasuk adanya pertambahan tinggi bibit yang lebih baik pula. Seperti diketahui Pugam T tidak saja mengandung unsur makro, tetapi juga mengandung unsur mikro (Tabel 1) apabila diberikan pada tanaman dalam jumlah yang seimbang maka dapat memberikan dampak positif pada tanaman tersebut. Misalnya $\mathrm{P}_{2} \mathrm{O}_{5}$ yang terkandung pada Pugam $\mathrm{T}$ akan menambah

Tabel 3. Hasil uji beda rata-rata berat segar bibit (gram) dan panjang akar primer (cm)

\begin{tabular}{ccc}
\hline Perlakuan & Berat Segar Bibit & Panjang Akar Primer \\
\hline $\mathrm{P}_{0} \mathrm{~N}_{0}$ & $1,52 \mathrm{a}$ & $9,37 \mathrm{a}$ \\
$\mathrm{P}_{0} \mathrm{~N}_{1}$ & $1,65 \mathrm{ab}$ & $10,73 \mathrm{~b}$ \\
$\mathrm{P}_{0} \mathrm{~N}_{2}$ & $2,55 \mathrm{abc}$ & $11,36 \mathrm{bc}$ \\
$\mathrm{P}_{0} \mathrm{~N}_{3}$ & $2,67 \mathrm{bc}$ & $12,12 \mathrm{~cd}$ \\
$\mathrm{P}_{1} \mathrm{~N}_{0}$ & $3,18 \mathrm{~cd}$ & $12,35 \mathrm{de}$ \\
$\mathrm{P}_{1} \mathrm{~N}_{1}$ & $4,13 \mathrm{be}$ & $12,43 \mathrm{de}$ \\
$\mathrm{P}_{1} \mathrm{~N}_{2}$ & $4,64 \mathrm{ef}$ & $13,25 \mathrm{ef}$ \\
$\mathrm{P}_{1} \mathrm{~N}_{3}$ & $5,17 \mathrm{ef}$ & $13,66 \mathrm{fg}$ \\
$\mathrm{P}_{2} \mathrm{~N}_{0}$ & $5,29 \mathrm{f}$ & $14,23 \mathrm{gh}$ \\
$\mathrm{P}_{2} \mathrm{~N}_{1}$ & $6,41 \mathrm{~g}$ & $14,68 \mathrm{hi}$ \\
$\mathrm{P}_{2} \mathrm{~N}_{2}$ & $7,37 \mathrm{gh}$ & $15,25 \mathrm{ij}$ \\
$\mathrm{P}_{2} \mathrm{~N}_{3}$ & $8,17 \mathrm{hi}$ & $15,60 \mathrm{j}$ \\
$\mathrm{P}_{3} \mathrm{~N}_{0}$ & $8,60 \mathrm{i}$ & $16,70 \mathrm{k}$ \\
$\mathrm{P}_{3} \mathrm{~N}_{1}$ & $10,55 \mathrm{j}$ & $18,42 \mathrm{I}$ \\
$\mathrm{P}_{3} \mathrm{~N}_{2}$ & $13,12 \mathrm{k}$ & $22,13 \mathrm{~m}$ \\
$\mathrm{P}_{3} \mathrm{~N}_{3}$ & $16,68 \mathrm{I}$ & $26,08 \mathrm{n}$ \\
\hline $\mathrm{BNJ} 5 \%$ & 1,14 & 0,91 \\
\hline Keterangan & Angka-angka yang didampingi huruf yang sama pada kolom yang sama tidak berbeda nyata
\end{tabular}


ketersediaan $\mathrm{P}$ dalam tanah dan mampu meningkatkan serapan $\mathrm{P}$ oleh akar tanaman. $\mathrm{P}$ berperan untuk memacu pertumbuhan akar dan pembentukan sistem perakaran, juga sebagai bahan penyusun inti sel, lemak dan protein. $\mathrm{K}_{2} \mathrm{O}$ berperan dalam meningkatkan unsur $\mathrm{K}$ di dalam tanah. Seperti diketahui Kalium merupakan unsur esensial bagi tanaman yang berfungsi untuk mengatur berbagai mekanisme metabolik seperti fotosintesis, translokasi karbohidrat dan sintesa protein sehingga meningkatkan ketahanan tanaman terhadap penyakit. $\mathrm{CaO}$ dan $\mathrm{MgO}$ berperan dalam meningkatkan ketersediaan unsur $\mathrm{Ca}$ dan $\mathrm{Mg}$ yang merupakan sistem enzim pembentuk klorofil, juga sebagai kofaktor dari berbagai enzim dalam tanaman. $\mathrm{Fe}, \mathrm{Al}, \mathrm{Mn}$ dan Zn salah satu fungsinya sebagai zat pembentuk hijau daun. Zat hijau daun merupakan syarat utama terjadinya proses fotosintesis pada tanaman (Dwidjoseputro, 2000).

Pertumbuhan vegetatif tanaman umumnya lebih memerlukan unsur nitrogen yang lebih banyak dibandingkan unsur hara lainnya sehingga dengan perberian pupuk Urea berarti menyediakan $\mathrm{N}$ yang lebih tinggi sehingga mampu menstimulir peningkatan pertumbuhan vegetatif tanaman seperti tinggi bibit. Seperti diketahui nitrogen berfungsi sebagai pembentuk klorofil, protein dan lemak. Nitrogen juga sebagai penyusun enzim yang terdapat dalam sel, sehingga mempengaruhi pertumbuhan karbohidrat yang sangat berperan dalam pertumbuhan tanaman (Lingga, 2004). Sosrosoedirdjo (2004) menambahkan bahwa karbohidrat merupakan bahan yang sangat diperlukan dalam pembelahan sel, perpanjangan sel, pembesaran sel dan pembentukkan jaringan untuk perkembangan batang, daun dan akar.

Untuk parameter jumlah daun, pemberian Pugam $T$ dan Urea secara bersama-sama maupun secara tunggal tidak menunjukkan adanya pengaruh nyata atau sangat nyata pada setiap umur pengamatannya. Hal ini diduga karena tanaman kelapa sawit merupakan tanaman tahunan sehingga pertumbuhan bibit khusunya perkembangan daun pada pembibitan pre nursery masih pada taraf pertumbuhan lambat, sehingga interaksi kedua perlakuan yang diberikan tidak terjadi. Gardner, Pearce dan Mitchell (1991), mengemukakan bahwa pertumbuhan tanaman terdiri dari tiga fase pertumbuhan, yaitu fase logaritmik (fase lambat), fase linear (fase konstan) dan fase asimptotik (fase kelayuan). Pada fase logaritmik pertumbuhan tanaman berlangsunglambat pada awalnya tetapi kemudian berlangsung semakin cepat. Fase ini umumnya berlangsung pada 1-3 minggu pada tanaman semusim dan 1-3 bulan pada tanaman tahunan. Fase linear yaitu fase pertumbuhan tanaman berjalan konstan, fase asimptotik dicirikan dengan laju pertumbuhan tanaman semakin menurun.

Untuk parameter diameter batang, sama halnya dengan parameter tinggi bibit, dimana rata-rata diameter batang terbesar pada setiap umur pengamatannya dihasilkan oleh perlakuan pemberian Pugam $T$ sebesar $1.250 \mathrm{~kg} / \mathrm{ha}$ dan Urea sebesar 3 gram/liter $\left(\mathrm{P}_{3} \mathrm{~N}_{3}\right)$. Hal ini disebabkan karena kedua unsur tersebut secara bersama-sama mampu memberikan pertumbuhan tanaman yang baik. Pertumbuhan yang baik diindikasikan dengan kemampuan tanaman untuk berfotosintesis lebih tinggi dan hasil fotosintesis 
(fotosintat) yang dihasilkan lebih banyak. Fotosintat yang lebih banyak ditranslokasi lewat floem dan dapat digunakan untuk memacu pertumbuhan sekunder yaitu perluasan sel batang dan diindikasikan dengan diameter batang yang lebih besar. Menururt Gardner dkk (1991) pertumbuhan dan perkembangan tanaman dan organ-organnya akaan bergantung oleh tersedianya meristem, hormon dan hasil fotosintesis (karbohidrat) serta lingkungan yang mendukung. Meristem lateral menghasilkan selsel baru yang memperluas lebar atau diameter suatu organ. Kambium vaskuler merupakan suatu meristem lateral yang terspesialisasi yang membentuk xilem dan floem sekunder. Loveless (1987), menambahkan bahwa pertambahan diameter batang terkait oleh adanya pertumbuhan sekunder termasuk pembelahan sel di daerah kambium dan pembentukkan xilem dan floem.

Pada parameter panjang akar primer, dimana panjang akar terpanjang dihasilkan oleh pemberian Pugam $T$ sebesar $1.250 \mathrm{~kg} / \mathrm{ha}$ dan Urea sebesar 3 gram/liter $\left(\mathrm{P}_{3} \mathrm{~N}_{3}\right)$. Hal ini disebabkan karena $\mathrm{P}_{2} \mathrm{O}_{5}$ yang terkandung pada Pugam $T$ menambah ketersediaan unsur $P$ di dalam tanah, demikian juga Urea yang diberikan mampu menambah ketersediaan $\mathrm{N}$ untuk menunjang pertumbuhan Tanaman. Peranan $P$ pada pertumbuhan tanaman adalah untuk memacu pertumbuhan akar dan pembentukkan sistem perakaran. Dengan meningkatnya panjang akar, maka penyerapan unsur hara khususnya nitrogen bisa lebih optimal (Dwidjoseputro, 2000).

Adanya pengaruh positif terhadap peningkatan berat segar bibit, hal ini disebabkan karena adanya peningkatan terhadap tinggi bibit, jumlah daun, diameter batang dan panjang akar primer. Lingga (2004) menyatakan bahwa pertumbuhan tanaman tergantung pada imbangan fotosintesis yang mengimbangi karbohidrat dan bahan tanam serta respirasi. Fotosintesis pada umumnya terjadi pada hijau daun yang berklorofil, maka sampai fase tertentu laju fotosintesis akan meningkat dengan meningkatnya jumlah daun serta pertumbuhan tanaman akan mengikutinya.

\section{KESIMPULAN DAN SARAN}

Kesimpulan

Interaksi pemberian Pugam $\mathrm{T}$ dan Urea berpengaruh sangat nyata terhadap para meter tinggi bibit, diameter batang, panjang akar primer dan berat segar bibit. Sedangkan untuk parameter jumlah daun, interaksi kedua perlakuan tersebut tidak berpengaruh nyata atau sangat nyata.

Hasil tertinggi untuk parameter tinggi bibit umur 4,8 dan 12 MST $(10,57 \mathrm{~cm}, 31,03 \mathrm{~cm}$, dan $35,00 \mathrm{~cm}$ ), diameter batang umur 4,8 dan $12 \mathrm{MST}$ $(0,57 \mathrm{~cm}, 0,66 \mathrm{~cm}$, dan $0,90 \mathrm{~cm})$, panjang akar primer $(26,08 \mathrm{~cm})$, berat segar bibit (16,68 gram) diperoleh pada perlakuan interaksi pemberian Pugam T dengan dosis $1.250 \mathrm{~kg} / \mathrm{ha}$ dan Urea dengan dosis 3 gram/liter $\left(\mathrm{P}_{3} \mathrm{~N}_{3}\right)$.

\section{Saran}

Dalam melakukan pembibitan kelapa sawit pada tahapan pre nursery di tanah gambut disarankan untuk mempertimbangkan pemakaian Pugam $T$ sebesar $1.250 \mathrm{~kg} / \mathrm{ha}$ dengan Urea sebesar 3 gram/liter.

\section{DAFTAR PUSTAKA}

Agus, F. dan I.G. M. Subiksa. 2008. Lahan Gambut : Potensi untuk Pertanian dan Aspek Lingkungan. Balai Penelitian Tanah dan World Agroforestry Centre (ICRAF), Bogor, Indonesia. 
Anonim. 1997. Petunjuk Teknis Budidaya Kelapa Sawit. Departemen Pertanian. Direktorat Jendera Perkebunan. Jakarta.

Anonim. 2008a. Pedoman Teknis Pembibitan Kelapa Sawit (pre nursery). PT. Socfin Indonesia. Medan

Anonim. 2008b Kiat Sukses Pembibitan Kelapa Sawit. www.google.com Tanggal Akses 27 Maret 2012.

Anonim. 2009a. Pembibitan Kelapa Sawit. www.google.com Tanggal Akses 28 Maret 2012.

Anonim. 2009b. Pemerintah Akan membangun Lembaga Riset Kelapa Sawit Bersekala Besar. $\quad h t t p: / / d i t j e n b u n . d e p t a n . g o . i d$. Tanggal akses : 27 Maret 2012.

Buckman, D.H. dan Brady, H. 1982. IImu Tanah. Bharata Karya Aksara. Jakarta.

Dwidjoseputro. 2000. Pengantar Fisiologi Tumbuhan. PT. Gramedia. Jakarta

Gardner, F, Pearce, R.B. dan Mitchell, R.L., 1991. Fisiologi Tanaman Budidaya. Universitas Indonesia Press. Jakarta.

Indranada, 2004. Pengelolaan Kesuburan Tanah. CV. Bina Aksara. Jakarta.

Lingga. 2004. Petunjuk Penggunaan Pupuk. Penebar Swadaya. Jakarta.

Loveless, A.R. 1987. Prinsip-prinsip Biologi Tumbuhan Untuk Daerah Tropik. Jilid I. Gramedia. Jakarta

Pauliz Budi Hastuti. 2011. Pengelolaan Limbah Kelapa Sawit Penerbit Deepublis Yogyakarta

Risza, S. 1993. Kelapa Sawit, Upaya Peningkatan Produktiitas. Penerbit Kanisius. Yogyakarta.

Ruswendi. 2008. Kelapa Sawit Indonesia. Pusat Penelitian Perkebunan Marihat. Bandar Kuala. Pematang Siantar. Sumatera Utara.
Samangun, Haryono, Aziz Lahija. 1985. Kelapa Sawit. Lembaga Pendidikan Perkebunan. Yogyakarta.

Setyamidjaja, D. 2006. Budidaya Kelapa Sawit. Penerbit Kanisius. Yogyakarta.

Soepardi, G. 1988. Sifat dan Ciri Tanah. Departemen IImu Tanah IPB. Bogor

Subiksa, IGM, dan Wiwik Hartatik. 2011. Pengelolaan Lahan Gambut Berkelanjutan, Materi pelatihan ICCTF Kalimantan Tengah.

Sukamto. 2008. Kiat Meningkatkan Produktivitas dan Mutu Kelapa Sawit. Penebar Swadaya. Depok

Sunarko. 2009. Budidaya dan Pengelolaan Kebun Kelapa Sawit dengan Sistem Kemitraan. Agromedia Pustaka. Jakarta.

Tim Penulis Penebar Swadaya. 1992. Kelapa Sawit, Usaha Budidaya, Pemanfaatan Hasil dan Aspek Pemasaran. Penebar Swadaya. Jakarta. 